\title{
Labyrinthe
}

31 | 2008 (3)

Revues modes d'emploi

\section{Le Triomphe de la mort}

Brèves notes sur Gomorra, de Matteo Garrone

\section{Renaud Pasquier}

\section{(2) OpenEdition}

\section{Journals}

Édition électronique

URL : http://journals.openedition.org/labyrinthe/3882

DOI : $10.4000 /$ labyrinthe.3882

ISSN : 1950-6031

Éditeur

Hermann

Édition imprimée

Date de publication : 15 octobre 2008

ISBN : 978-2-9526131-8-7

Référence électronique

Renaud Pasquier, « Le Triomphe de la mort », Labyrinthe [En ligne], 31 | 2008 (3), mis en ligne le 08

novembre 2008, consulté le 24 septembre 2020. URL : http://journals.openedition.org/labyrinthe/3882 ; DOI : https://doi.org/10.4000/labyrinthe.3882

Ce document a été généré automatiquement le 24 septembre 2020.

Propriété intellectuelle 


\section{Le Triomphe de la mort}

Brèves notes sur Gomorra, de Matteo Garrone

\section{Renaud Pasquier}

INDEX

Mots-clés : Camorra

Index géographique : Italie, Naples 